This is a self-archived version of an original article. This version may differ from the original in pagination and typographic details.

Author(s): Palviainen, Åsa; Bergroth, Mari

Title: Parental discourses of language ideology and linguistic identity in multilingual Finland

Year: 2018

Version: Accepted version (Final draft)

Copyright: (c) 2018 Informa UK Limited, trading as Taylor \& Francis Group

Rights: In Copyright

Rights url: http://rightsstatements.org/page/InC/1.0/?language=en

Please cite the original version:

Palviainen, Å., \& Bergroth, M. (2018). Parental discourses of language ideology and linguistic identity in multilingual Finland. The International Journal of Multilingualism, 15(3), 262-275. https://doi.org/10.1080/14790718.2018.1477108 


\title{
Parental discourses of language ideology and linguistic identity in multilingual Finland
}

\author{
Åsa Palviainen ${ }^{\mathrm{a} *}$ and Mari Bergroth ${ }^{\mathrm{b}}$ \\ ${ }^{a}$ Department of Language and Communication Studies, University of Jyväskylä, \\ Jyväskylä, Finland \\ *Department of Language and Communication Studies, P.O. Box 35, FIN-40014 \\ University of Jyväskylä. Telephone: +358-40-8053217, e-mail asa.palviainen@jyu.fi \\ ORCID: 0000-0003-2778-2834
}

${ }^{\mathrm{b}}$ Education (Teacher Oriented), Åbo Akademi University, Vaasa, Finland

Faculty of Education and Welfare Studies, Rantakatu 2, FIN-65101 Vaasa.

Biographical notes: Åsa Palviainen is Professor of Swedish at the Department of Language and Communication Studies at University of Jyväskylä. Mari Bergroth is Associated Professor in Education (Teacher Oriented) at Åbo Akademi University. 


\title{
Parental discourses of language ideology and linguistic identity in multilingual Finland
}

\author{
Abstract
}

Finland is officially a bilingual country but it is in practice multilingual. In the current study, we examined how mothers and fathers of mixed-language families linguistically identified themselves and others, and how ideological discourses and concepts historically and socially situated in Finland circulated through the parents' talk. The parents of three families in which at least Finnish, Swedish and English were used on a daily basis were interviewed. A discourse nexus approach showed that the concept of 'mother tongue(s)' played a central role and that although all family members were in practice multilingual, there was a strong tendency across the couples to identify themselves and others as monolingual. Bilingualism was identified with Finnish-Swedish rather than other languages and a native discourse expressed bilingual identity as granted by birth rather than acquired later. The discourses could be traced back to official language registration procedures, the educational system in Finland, as well as to parents' own lived experiences. The study illustrates the intricate relationships between language ideologies and how linguistic identities are created and performed among parents, and it pinpoints the need for further studies on how linguistic identities are passed on to and experienced by children along their life trajectories.

Keywords: language ideology; linguistic identity; mixed-language families; Finland; nexus analysis

\section{Introduction}

Finland is a multilingual country with two equal national languages, Finnish and

Swedish. The Sámi as an indigenous group and the Roma, as well as 'other' language groups and users of sign languages, are also acknowledged in the Constitution of Finland 1999. Multilingualism is further emphasised by migration in Finland even 
though the number of migrants is still small compared with the numbers in other Nordic countries (Honko \& Latomaa, 2016). There is a conscious education policy of promoting multilingual skills and identities, as reflected in the recently implemented national core curriculum for basic education (FNBE, 2014), and there is a long tradition of formal language teaching: it is compulsory for schoolchildren to study the national languages (Finnish and Swedish), and in addition to these, at least one 'foreign' language (English), with the option of studying further languages (e.g. German, French, or Spanish).

As a result of its language legislation, Finland has a system of official registration of the linguistic affiliation of its citizens; each individual is assigned an official language referred to as his/her 'mother tongue'. At the moment it is only possible to report one mother tongue; the statistics thus say very little about individual multilingualism and societal linguistic diversity (see Moore, Pietikäinen \& Blommaert 2010 for a critical account of numerical representations of speakers). Based on the official statistics, $88.3 \%$ of the population have Finnish, $5.3 \%$ have Swedish, and 6.4 $\%$ have other languages as their mother tongue. The largest 'other' languages are Russian, Estonian, Arabic and Somali (Official Statistics of Finland, 2017). Despite the fact that Finland is multilingual, there is a prominent national identity discourse of Finland as bilingual, which refers to Finnish and Swedish (Halonen, Ihalainen \& Saarinen, 2015; also Hult \& Pietikäinen, 2014).

In the current study, parents of three mixed-language families in Finland who regularly used (at least) Finnish and Swedish were interviewed. During these interviews, parents made frequent references to other languages as well. The focus is on how the parents discursively co-construct and negotiate their own and their children's language and cultural identities, and in doing this, how they circulate official language 
ideologies. Finnish and Swedish speakers have shared their territory and lived side-byside for many centuries (McRae, 2007). Therefore, the cultural context can be "imagined as a homogeneous space" involving very close cultural proximity, which is often argued to be "unproblematic or at least less problematic than cultural distance" (Piller, 2002, p. 6). In this sense, the study complements prior research about binational family constellations where parents speak languages of high prestige but where the cultures are only relatively close (e.g. Gonçalves, 2013; Piller 2002; Teiss \& Perendi, 2017) or are quite distant (e.g. Okita, 2002; Zhu Hua \& Li Wei, 2016). This close cultural proximity opens the way for potentially different patterns of family language policy negotiation and experiences of linguistic identity than have hitherto been explored.

The research questions which we examine are the following: 1) How do parents linguistically (and culturally) identify themselves, and negotiate and ascribe identities to each other and to their children? 2) How are the linguistic identities formulated and negotiated by the parents related to their own lived experiences, on the one hand, and to societally situated discourses and ideologies, on the other? The data analysed were semi-structured interviews with the parent couples. In order to identify the discourses and concepts that were foregrounded and negotiated by the participants we applied a nexus analytical approach (Scollon \& Scollon, 2004).

\section{Ideology and identity in multilingual families}

In the case of multilingual families in Finland, the system of language registration imposes parental agency, since the parents choose the official mother tongue of their child and also the primary language of instruction in school. The registered mother tongue can, however, be changed at any time without explanation. The school system 
has parallel Finnish and Swedish tracks providing education in either of the two languages from early childhood to university level. In the current study, all three families had made an informed choice (cf. Kalaja, Barcelos, Aro \& Ruohotie-Lyhty, 2016, p. 19) of Swedish-track early childhood education for their children. They also employed a multilingual language policy and multilingual practices at home. Hence, their family language policy involved explicit and overt planning in relation to language use (King, Fogle \& Logan-Terry, 2008) as well as more implicit and covert planning and practices (e.g. Curdt-Christiansen, 2013; Fogle, 2012; King \& Fogle, 2017, Palviainen \& Boyd, 2013).

Beliefs and attitudes about languages and language development play a significant role in mixed-language families. By way of example, on the basis of these beliefs, parents may employ certain language practices which they think will lead to a certain result (e.g. De Houwer, 1999; Piller, 2001; Schwartz \& Verschik, 2013). Ideology, which in this article is seen as "a set of beliefs" and as "the underlying thought system that is expressed through discourse - language in action” (Määttä \& Pietikäinen, 2014, p. 8), therefore interacts with agency in the complex web of actions that mediate family language policy (King \& Lanza, 2017). Beliefs indicate that individuals or a community accept something as true, and they are at the same time context-dependent, dynamic and possibly even conflicting (Kalaja et al., 2016, p. 10). 'Mother tongue', as mentioned above, is an example of a socially and historically constructed concept (Hult, 2015) that can play out in complex ways as ideological discourse. In one sense, the mother tongue can be very emotionally loaded and closely connected with personal lived experience and identity. In another sense, as Liebkind, Tandefelt and Moring (2007) point out, it can also be merely a bureaucratic term with little content: "people [in Finland] are quite used to the concept of 'mother tongue' 
because that is a concept that is the expression used in several official registers and documents" (p. 5). The Finnish system, in which everyone is allocated 'one mother tongue', was originally developed in order to serve as a numerical basis for deciding whether a municipality or local authority was bilingual and therefore obliged to provide services in both Finnish and Swedish (or Sámi). As we will argue, however, this system also has profound implications for how parents identify themselves and their children (see also Bergroth 2015).

Identity is constructed and negotiated in a socio-cultural context and refers to "people's understanding of their relationship to the world" (Norton 1997, p. 410). As identities are socially and discursively (co-)constructed (Bucholtz \& Hall, 2005), they are also dynamic and shifting and can serve as a site of struggle and negotiation of difference and ambivalence (Block, 2007; Piller, 2002). Piller (2002) contends that identity is not "a matter of labels and categories but rather one of performance" (p. 12); therefore, from a linguistic perspective, she argues that language and social identity are mutually constitutive. We argue that it is important to place the notion of linguistic identity as the focus of analysis and to ask, on the one hand, who has the agentive right to claim a certain linguistic identity as their own in a multilingual family and, on the other hand, who has the agentive right - and on what grounds - to deny another's bilingual or multilingual identity within the same family.

Our focus in this article is on the meaning-making processes parents use when constructing their linguistic identity and how these connect with language ideologies. We aim to capture linguistic identities as they are performed and negotiated by parents through their talk. We will also explore how the linguistic identities are constructed as a function of the parents' personal language ideologies and their personal trajectories of language learning, and how these align with larger cycles of public discourses. 


\section{Data collection and participants}

The present study was a part of a larger ethnographically informed research project focusing on mixed-language families in Finland in which there were children between 3-5 years of age attending Swedish early childhood education (ECE). The families were recruited via the ECE centres. As a criterion for participation, the parents had to have different languages (Swedish or Finnish) registered as their official mother tongue. The data used was from interviews carried out with the parents in three of the families, who lived in two different cities. The Pitkänen and the Kuusisto-Lindström couples lived in Weston, an officially bilingual city, while the Kivistö couple lived in Middleton, an officially monolingual Finnish city (see Table 1). In Weston, $69 \%$ of the population had Finnish, $23 \%$ Swedish, and $8 \%$ other languages as their registered mother tongue whereas in Middleton, $95 \%$ of the population were registered as Finnish speakers and 5 $\%$ as speakers of other languages (Official Statistics of Finland, 2017.)

The interviews followed a structured protocol (Mann, 2016), each one including the same set of questions, which dealt with the participants' language background, languages studied at school and used at work, language choices at home, definitions of bilingualism, and multilingual contacts in the family's daily life. The interviews were between 45 and 60 minutes long and were carried out by the second author, who is multilingual. The participants could choose which language(s) to use in the interviews: the Pitkänen and Kivistö couples used mainly Finnish and the Kuusisto-Lindström couple used Swedish as well as Finnish. The interview excerpts below are provided in the original language as well as translated into English. 
Table 1. Participants, their reported language backgrounds, place of residence and children.

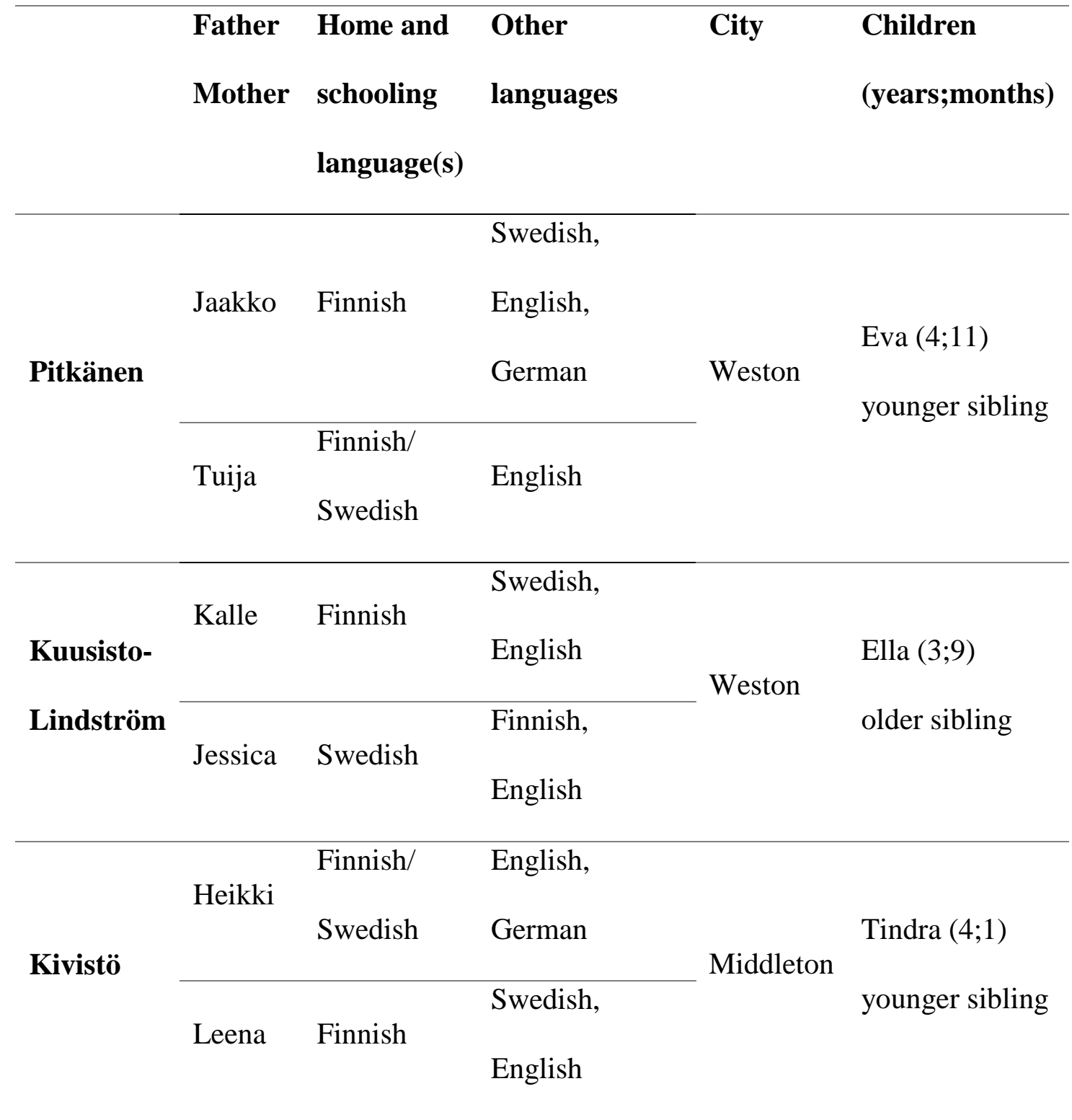

\section{Data analysis}

The interviews were analysed as a part of a larger set of data with a nexus analytic approach. We see interview material as rich data to tap parental discourses about language ideologies and linguistic identities and a nexus approach makes it possible to disentangle and analyse complex layers of discourse (Palviainen \& Boyd, 2013). At the 
core of nexus analysis is a social action (Scollon \& Scollon, 2004), which in this study is the parental co-construction of linguistic identities in talk. A social action is situated at the intersection of the historical body of the individuals, the interaction order which they mutually produce among themselves, and the discourses in place that enable that action (Scollon \& Scollon, 2004, pp. 153-154). In our analysis, we therefore carried out mapping and circumferencing discourse analysis of the lived experiences and language learning trajectories of, and beliefs held by, the individual parents (the historical body); norms of interaction and expectations about social roles - or - participants and their significance (the interaction order); and the situated context in which action took place, including ideologies, socially and historically situated concepts and norms of interpretation (the discourses in place) (Hult, 2015). With the two research questions in mind, we mapped relevant people, places, discourses, objects, and concepts (Scollon \& Scollon, 2004, pp. 159-160) in the parental talk and analysed how these were negotiated between the parents. We also identified connections with larger cycles of societal and historical discourses.

Notably, neither of the concepts 'ideology' or 'identity' were mentioned in the interviews by either researchers or parents, yet they are an integral part of the individuals' historical body and of the discourses in place. The concepts also play out in interaction orders and they therefore functioned as tools facilitating our analysis and understanding of the social action at hand. In the following sections, we present the results of the nexus analyses of the three families in turn: the Pitkänens, the LindströmKuusistos, and the Kivistös.

\section{Results}

\section{The Pitkänen couple}


Jaakko and Tuija Pitkänen both grew up in Finnish-speaking homes in the Weston area, but whereas Jaakko went to a Finnish-medium school, Tuija attended a Swedishmedium one. Jaakko had studied Swedish, English and German at school, and he was now enrolled in a Finnish-English university programme. Both Jaakko and Tuija used Finnish, Swedish and English in their work. With these backgrounds they were what Kramsch (2009, p. 17) refers to as 'multilingual subjects'.

The concept of 'bilingualism', for both of them, referred explicitly to (speakers of) Finnish and Swedish. For example, in the following excerpt, Jakko reported "this bilingualism" as being the natural state of affairs in the Weston surroundings where he grew up (Excerpt [1]; transcription conventions to be found at the end of the article ${ }^{\mathrm{i}}$ ):

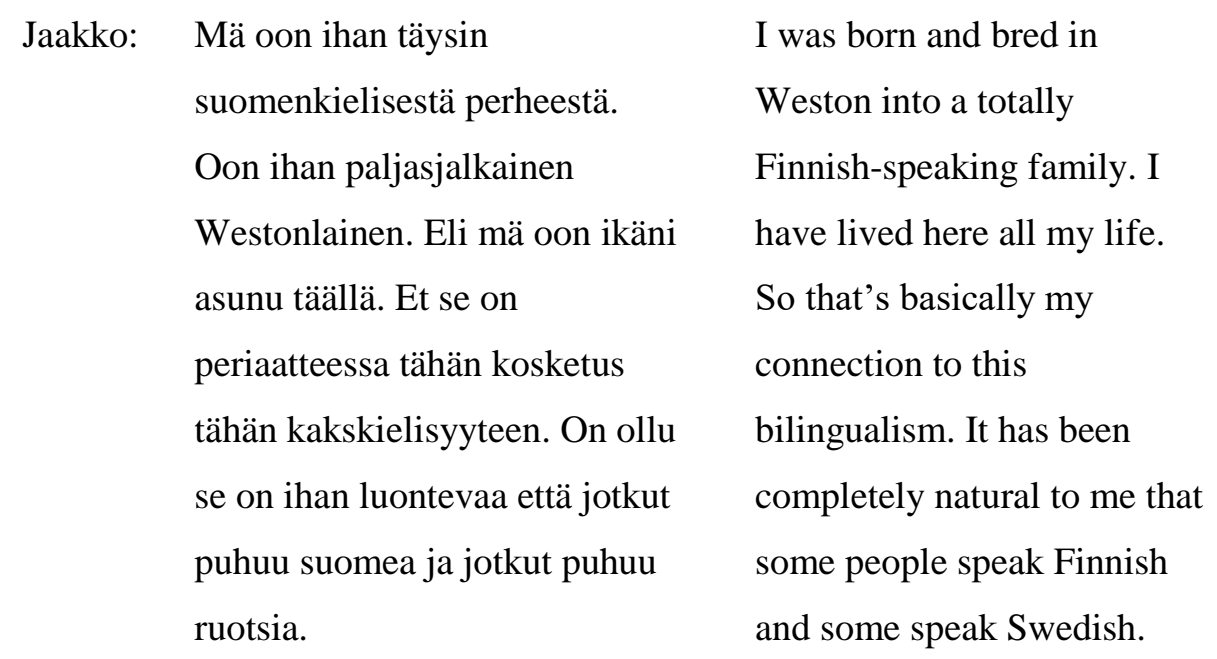

Tuija had a Swedish-speaking father but Finnish was the home language during her childhood. When Tuija described her linguistic identity, she revealed its complexity (Excerpt [2]):

Tuija: Mä en oikeastaan tunne itseäni I don't really feel that I'm really ihan ruotsinkieliseks, mä en a Swedish speaker, and I don't 
tunne itseäni ihan

suomenkieliseks. Tai sitten

enemmän ehkä mun sydämen

kieli on suomi siks että se on

tavallaan niinku se äidin- $\underline{\text { mun }}$

äidin äidinkieli. Ni mä ehkä koen

itseni enemmän suomenkieliseksi

kun ruotsinkieliseksi. feel I'm really a Finnish

speaker. Or then more perhaps

that the language of my heart is

Finnish, since it is mother's-

my mother's mother tongue. So

I maybe feel more like a

Finnish speaker than a Swedish

speaker.

She thus initially stated that she felt that she was neither a Swedish-speaker nor a

Finnish-speaker, but then announced that Finnish was the language of her heart because she had inherited it from her own mother. Later in the interview, she ascribed a similar identity to her 4-year-old daughter: bilingual, but more Finnish than Swedish (Excerpt [3]).

Tuija: Eva on kakskielinen. Mutta ehkä mä sanoisin enemmän että suomen, myös sitä sydämeltään suomenkielinen. Jos mä niinku itteeni kuvailisin näin niin tällä hetkellä ehkä Eva on myöskin näin.
Eva is bilingual. But maybe I would say more Finnish, also in her heart Finnish speaking. If I describe myself like that, she is perhaps like that too, at this point.

According to Tuija, Eva also had a strong emergent interest in English: Evalla on just se englanti nyt joku vähän sellanen vaihe et hän sanoo että 'thank you' että 'mä tiedän mitä se tarkoittaa' ("as for English, Eva is now at the stage when she says 'thank you' and 'I know what that means"').

In the following excerpts [4a and b], Jaakko and Tuija were discussing whether they count as bilingual, still assuming that it is about Finnish and Swedish: 
Tuija: Mää koen että mä oon

kakskielinen ja mä huomaan

sen siinä, että mä en osaa

kumpaakaan kieltä kunnolla.
I feel that I'm bilingual and I

notice it in the sense that I

don't know either of the two

languages properly.

[4b]

$\begin{array}{lll}\text { Jaakko: } & \text { No en mää osaa sanoa että mä } & \text { Well at least I can’t say that I } \\ \text { oisin ainakaan kovin vahvasti } & \text { would be very strongly } \\ \text { kaksikielinen, en mä nyt tässä } & \text { bilingual, not at this age. I so } \\ \text { iässä. Täs tavallaan on } & \text { to speak in inverted commas } \\ \text { lainausmerkeissä joutunut } & \text { have had to learn the } \\ \text { opettelemaan sitten kielen. } & \text { language. }\end{array}$

Whereas Tuija acknowledged her bilingualism by virtue of not knowing either of the two languages (Swedish and Finnish) properly, Jaakko declared that he was not "very strongly" so. He pointed out that he had learned Swedish ("the language") only when he was older. Tuija had a very definite opinion about Jaakko's bilingualism (Excerpt [5]):

[5]

$\begin{array}{lll}\text { Tuija: } & \begin{array}{l}\text { Niin ja mä näkisin ettei Jaakko } \\ \text { millään lailla kaksikielinen. }\end{array} & \begin{array}{l}\text { As I see it, Jaakko is not } \\ \text { bilingual in any sense. As I }\end{array} \\ \begin{array}{l}\text { Että mä näkisin et Jaakko on } \\ \text { suomenkielinen mutta se osaa } \\ \text { ruotsia ja osaa käyttää töissä. Ja }\end{array} & \begin{array}{l}\text { see it Jaakko is a Finnish } \\ \text { speaker but he knows }\end{array} \\ \text { sillä lailla että osaa ruotsia ja } & \text { work. And in that he knows } \\ \text { sillä lailla kun ajattelee että } & \text { Swedish, and considering } \\ \text { osaa englantiakin, englantia on } & \text { that he knows English as } \\ \text { oppinut jo koulussa } & \text { well, he has learned English } \\ \text { nuorempana. Ni tavallaan ku } & \text { already in school when he } \\ \text { ruotsia sä esimerkiks etkä sä } & \text { was younger, still, in the } \\ \text { silti voi sanoo että sä oot niinku } & \text { same way as with Swedish, } \\ \text { englantilais-suomenkielinen } & \text { you can’t say that you are } \\ \text { kakskielinen siis sillälailla. Niin } & \text { like bilingual in English and } \\ \text { mä ainakin ajattelen sen } & \text { Finnish in that way. At least I }\end{array}$




\begin{tabular}{|c|c|c|}
\hline & jotenkin sillälailla että sitten & see it that we live in a \\
\hline & ruotsinkielisessä ympäristössä & Swedish-speaking \\
\hline & elää, no joo tavallaan joo, mutta & environment, yes, but I see it \\
\hline & että kyllä mä näkisin että= & that $=$ \\
\hline Jaakko: & =kyllä mä niinku ykskielinen & $=y e s$, it's like, I'm \\
\hline & oon, kun se on niinku tosiaan se & monolingual, because it's, it \\
\hline & on $=$ & really is $=$ \\
\hline Tuija: & $=$ sä osaat ruotsia ja englantia ja & $=$ you know Swedish and \\
\hline & näin mutta mun mielestä sä oot & English but in my opinion \\
\hline & tää on niinku mun näkemys & you are like-. \\
\hline Jaakko: & Joo että se on niinku & Yes it's like a part that has \\
\hline & tavallaan tänne pääkoppaan & been glued onto the brain, \\
\hline & niinku semmonen & something that has been put \\
\hline & päälleliimattu osio että se on & there later. \\
\hline & niinku tuotu sinne & \\
\hline & älkeenpäin. & \\
\hline
\end{tabular}

In this exchange, Tuija disqualified Jaakko as a bilingual: he was, rather, a Finnish speaker who knew Swedish and English. Jaakko, who first appropriated bilingualism as something relative (cf [4b]) eventually abandoned this interpretation and aligned with Tuija's conception of bilingualism as a question of either-or. In this way they ended up with a co-constructed identity for Jaakko as a Finnish speaker (even yksikielinen, "monolingual") who had some time later learned and added Swedish and English to his repertoire. The cognitive metaphor that Jaakko used for this process, "glued onto the brain", stands in stark contrast to the emotional heart metaphor Tuija used to describe herself and her daughter. This passage shows that not only is linguistic knowledge interactively assessed (Piller, 2002, p. 103), but so too is who has the right to be called bilingual and on what grounds (cf. O’Rourke, Pujolar \& Ramallo, 2015). In this case, it seems as if the spouses agreed that Tuija's childhood, and being born into a family with Finnish- and Swedish-speaking parents and attending a Swedish school, put her in a 
special position and made it legitimate for her to be called bilingual, whereas Jaakko was not in such a position.

\section{The Kuusisto-Lindström couple}

Kalle Kuusisto also grew up in a Finnish-speaking family in Weston and went to a

Finnish school. He described himself as ihan westonlainen and ihan täysin

suomenkielinen (“a born and bred Westoner"; “definitely a 100\% Finnish speaker”).

Jessica Lindström, his wife, also claimed to be riktigt Weston-bo ("a true Westoner")

but, in contrast to him, to be fullständigt svenskspråkig ("a $100 \%$ Swedish speaker")

(Excerpt [6]):

[6]

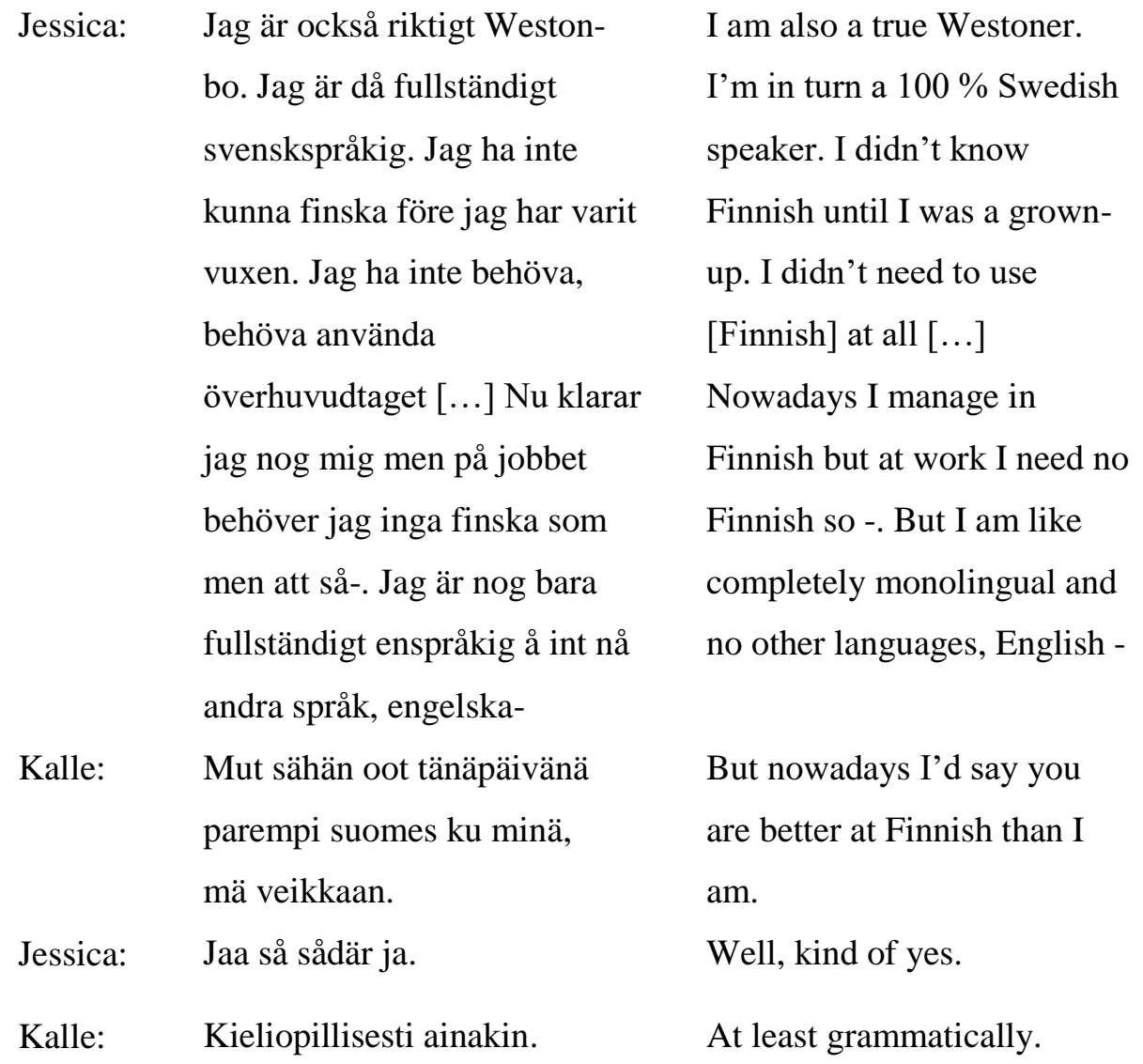

Although it was evident that Jessica and Kalle could speak both Swedish and Finnish - 
Kalle even pointed out that she outperformed him in Finnish - they both insisted on describing themselves as $100 \%$ speakers of either-or. In the following excerpt [7], Jessica elaborated on her interpretation that she was good at Finnish, but not good enough to count as a bilingual:

$\begin{array}{lll}\text { Jessica: } & \text { Jag är inte ännu tvåspråkig } & \text { I'm not bilingual yet as I } \\ & \text { eftersom jag kan int finska så } & \text { don’t speak Finnish so well. } \\ \text { bra. Människor runtomkring } & \text { People around me say that } \\ \text { mig säger att jag är duktig på } & \text { I'm good at Finnish but I } \\ \text { finska men jag själv har såhär } & \text { sometimes have days when I } \\ \text { att vissa dar så kan jag inte } & \text { can’t produce a word, } \\ \text { jag får inga ord allting blir fel } & \text { everything goes wrong. But } \\ \text { men att vissa dar flyter det på } & \text { some days I'm quite fluent. } \\ \text { riktigt bra men att jag är int. } & \text { But I'm not - I'm a Swedish- } \\ \text { Jag är svenskspråkig och kan, } & \text { speaker and I know I'm good } \\ \text { är bra på finska. } & \text { at Finnish. }\end{array}$

Her conclusion is that she is a Swedish speaker who is good at Finnish, but not good enough to count as a bilingual. In contrast, Jessica considered that their daughter was bilingual: Ella är tvåspråkig eftersom hon är född $i$ både finskt och svenskt ("Ella is bilingual because she was born into both Swedish and Finnish"). According to Jessica, bilingualism thus comes with birth, if both languages are represented by the parents. This nativeness ideology was strong in all three families. Later in the interview the parents mentioned that Ella had an emerging and strong interest in English, too, partly mediated by her older sister: När hon är här och sköter så ser de på filmerna på engelska för att hon skulle lära sig ("When she [the sister] is here and takes care of her [Ella] they watch films in English in order for her [Ella] to learn it"). 
In addition to proficiency and nativeness discourses, Jessica suggested that appropriation of cultures and traditions was an essential part of bilingualism. In the following excerpt [8], Jessica reflected on whether her husband qualified as bilingual:

\begin{tabular}{|c|c|c|}
\hline Jessica: & $\begin{array}{l}\text { Kalle tycker jag att börjar } \\
\text { snart bli tvåspråkig. Han har } \\
\text { varit ganska tvåspråkig länge } \\
\text { för vi har haft den där } \\
\text { kulturen vi har den där } \\
\text { svenskspråkiga kulturen som } \\
\text { han är som ändå från början. } \\
\text { Han har nu levt i den i } 21 \text { år } \\
\text { med alla traditioner o sånt att } \\
\text { du är nu som, du är } \\
\text { tvåspråkig, tycker jag att du- } \\
\text { Nå jag definierar å fast nu har } \\
\text { du ju vissa ord som du int } \\
\text { kanske- }\end{array}$ & $\begin{array}{l}\text { I think Kalle is soon getting } \\
\text { to be bilingual. He's been } \\
\text { fairly bilingual for quite } \\
\text { some time because we've } \\
\text { had this culture of Swedish } \\
\text { speakers from the very start. } \\
\text { He's lived with all the } \\
\text { traditions and so on for } 21 \\
\text { years so you are now like a, } \\
\text { or you are a bilingual I think- } \\
\text { Well, now I'm saying that, } \\
\text { but you do have some words } \\
\text { that you perhaps don't - }\end{array}$ \\
\hline Kalle: & Joo. ((tvekande) $)$ & Yeah. ((hesitant)) \\
\hline Jessica: & $\begin{array}{l}\text { Men att nog, jag tycker det för } \\
\text { att som med den där kulturen } \\
\text { att jag uppfattar int mig som } \\
\text { till exempel överhuvudtaget } \\
\text { som att jag med de här finska } \\
\text { traditionerna och leverlåda } \\
\text { och vet du alla era } \\
\text { konstigheter ni har, vet du så } \\
\text { här. ((skrattande)) }\end{array}$ & $\begin{array}{l}\text { But that - I think that, } \\
\text { because about that culture, } \\
\text { for myself I don't feel at all } \\
\text { for example that I have these } \\
\text { Finnish traditions and liver } \\
\text { casserole and you know all } \\
\text { these peculiarities you have, } \\
\text { you know. ((laughs)) }\end{array}$ \\
\hline
\end{tabular}

Jessica thus made bilingualism into an issue of biculturalism. The culture of Swedish speakers was opposed to that of Finnish speakers, the latter here to be represented by cultural artefacts (the dish leverlåda, "liver casserole"). She claimed that at the same time as Kalle was being socialised into the traditions of Swedish speakers, she was not 
being socialised into Finnish traditions. She even opened up the idea that Kalle could eventually legitimately claim to be bilingual. In response to Jessica's claims, Kalle said:

[9]

$\begin{array}{lll}\text { Kalle: } & \begin{array}{l}\text { No en mä nyt ihan vielä tunne } \\ \text { että mä olisin kaksikielinen. }\end{array} & \begin{array}{l}\text { Well, I don't think I quite yet } \\ \text { feel that I'm bilingual. But }\end{array} \\ \begin{array}{l}\text { Mutta tietysti varmaan } \\ \text { sillälailla niinkuin Jessica }\end{array} & \begin{array}{l}\text { it's of course for sure as } \\ \text { Jessica says that there are }\end{array} \\ \text { noin sanoi että varmaan se on } & \text { those traditions and I'm } \\ \text { se nää perinteet ja tää ja mä } & \text { fairly sure that I've become } \\ \text { oon varmaan ruotsalais- } & \text { Swedishiz- - no - I've } \\ \text { ruotsinkielistynyt kyllä aika } & \text { become Swedish-speakerized } \\ \text { pahasti varmaan tässä vuosien } & \text { to quite an extent during } \\ \text { varrella. } & \text { these years. }\end{array}$

It is not clear whether he agreed with Jessica that bilingualism equals being bicultural, but he did express the idea that he had been socialised into many Swedish cultural traditions over time. Discursively, he made a self-correction: instead of saying that he had been ruotsalaistunut ("Swedishized", become a Swede) - which refers to Sweden as a nation state and to Swedes - he said that he had been ruotsinkielistynyt ("Swedishspeakerized", become a Swedish-speaker), referring to Swedish speakers in Finland. Kalle had thus incorporated the norms of interaction of Swedish speakers (in Finland) and had become successfully assimilated into their linguistic and cultural community. This negotiation of cultural identities includes elements of pointing out differences and contains discourses of transformation and assimilation (Block, 2007; Kramsch, 2009).

\section{The Kivistö couple}

The third family lived in Middleton, a city heavily dominated by Finnish. Leena grew up in a small village in the countryside. She described herself as aika täysin suomenkielinen (“pretty much $100 \%$ Finnish speaker”) (Excerpt [10].) 


\begin{tabular}{|c|c|c|}
\hline \multirow[t]{9}{*}{ Leena: } & $\begin{array}{l}\text { Äidinkieli on suomi ja niin } \\
\text { mä oon lapsuuttani viettänyt }\end{array}$ & $\begin{array}{l}\text { My mother tongue is Finnish } \\
\text { and I spent my childhood in }\end{array}$ \\
\hline & Lakesidellä. Mä oon syntynyt & Lakeside. I was born in \\
\hline & Lakesidellä ja ja tota niin niin & Lakeside, and ehm, I'm pretty \\
\hline & mä oon aika täysin & much $100 \%$ a Finnish \\
\hline & suomenkielinen ((nauraa)) ja & speaker ((laughs)) and I've \\
\hline & mä oon aina kokenut et mä en & always had the feeling that \\
\hline & oo ees kielissä mitenkään & I'm not very gifted when it \\
\hline & hirveän lahjakas. Mä oon & comes to languages. I studied \\
\hline & lukenu ihan normaalit & English and Swedish at \\
\hline
\end{tabular}

Leena thus had a very strong identity as a Finnish speaker and stressed Finnish as her mother tongue. An important aspect of Leena's language learning trajectory and lived experience (i.e., in nexus terms: her historical body) was that when she studied English and Swedish at school, she felt that she was not good at them and that they were too difficult for her. She mostly used Finnish in her daily work and only on very rare occasions did she need to use English or Swedish. Leena's husband Heikki had a different background, as he had lived in Sweden for some time during his childhood. When the family moved to Finland, he went to Swedish-medium schools (Excerpt [11]):

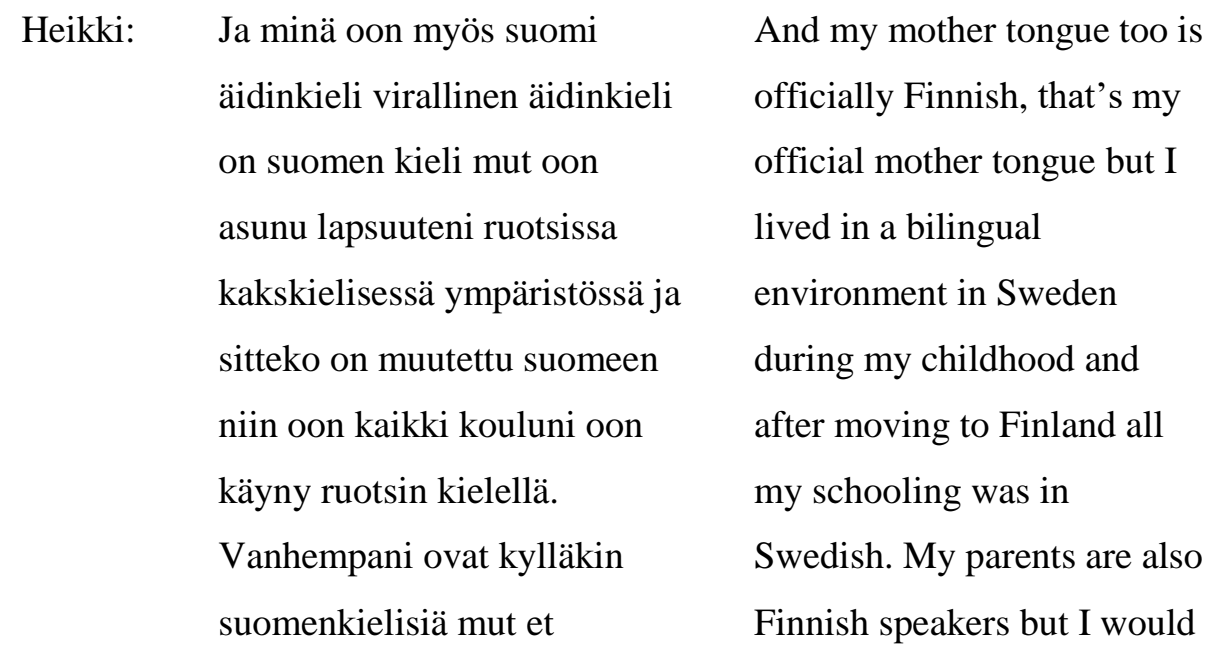




$$
\begin{array}{ll}
\begin{array}{l}
\text { sanotaan et ympäristöstä } \\
\text { johtuen ni oon kakskielinen. }
\end{array} & \begin{array}{l}
\text { say that because of my } \\
\text { environment I am bilingual. }
\end{array}
\end{array}
$$

In this excerpt, two intersecting discourses can be found: the first one indexing Heikki as a Finnish speaker by virtue of his official mother tongue and Finnish-speaking parents, and the other one pointing to his being Finnish-Swedish bilingual by virtue of the linguistic, sociocultural and educational environment. He further reported the regular use of English at work. One theme with this couple, pursued particularly by Leena, was that Heikki had a rich repertoire of language resources whereas Leena's repertoire was restricted. She even joked about it, awarding Heikki an international identity: Mä aina vitsailen että me ollaan tämmönen pariskunta et hän on kansainvälinen ja mä oon Lakesideltä ((nauraa)). ("I always joke that we're that kind of couple that he's international and I'm from Lakeside ((laughs))." Lakeside here stands for a rustic village, which gives strong connotations of Finnish (monolingual) speakers and Finnish culture (cf. also Excerpt [10]). Lakeside is thus a geographical place foregrounded by Leena as relevant (Scollon \& Scollon, 2004, p. 162) in explaining her identity.

In the following quote [12], Leena reflected on who counted as a bilingual:

$\begin{array}{lll}\text { Leena: } & \text { Minä en ole kaksikielinen ja } & \text { I'm not bilingual and in my } \\ \text { mun mielestä } & \text { opinion the definition of } \\ \text { kaksikielisyyden määritelmä } & \text { bilingualism is somehow that } \\ \text { on jotenkin se et hal- hallitsee } & \text { one has mastered it like, I } \\ \text { niinku mä en osaa sanoa sitä } & \text { can't say on what level. } \\ \text { mil- millä tasolla. Heikki } & \text { Heikki talks about grammar } \\ \text { puhu tosta kieliopi- kieliopista } & \text { and so on, but somehow it } \\ \text { ja muusta, mutta mut } & \text { means though that one has }\end{array}$




$\begin{array}{ll}\text { jotenkinhan se kuitenkin } & \text { sort of mastered both of the } \\ \text { tarkoittaa sitä, että että niinku } & \text { languages, even though one } \\ \text { hallitsee ne molemmat kielet, } & \text { of them is your mother } \\ \text { vaikka toinen on äidinkieli. Ja } & \text { tongue. And Tindra is } \\ \text { Tindra on kaksikielinen. } & \text { bilingual. }\end{array}$

In her view, in order to count as bilingual, in addition to the mother tongue (in the singular) you need to know another language sufficiently well. According to her, Tindra met these criteria. Heikki made a mild objection, that it is possible to have more than one mother tongue (Excerpt [13]). After hearing Heikki's arguments, Leena came up with this interpretation.

$\begin{array}{lll}\text { Heikki: } & \text { Jollainhan se voi olla } & \text { For some people, both of the } \\ \text { äidinkieli voi olla } & \text { languages can be the mother } \\ \text { molemmat että toi se voi } & \text { tongue and that can originate } \\ \text { tulla niinku taustalta sieltä } & \text { from your background that } \\ \text { että se on molemmilla } & \text { they are both mother tongues } \\ \text { äidinkieli. Mutta } & \text { for you. But a possible } \\ \text { jonkinlainen määritelmä } & \text { definition could also be that } \\ \text { voi myöskin olla et se se ei } & \text { it isn't a learned language, I } \\ \text { oo niin kuin opittu kieli siis } & \text { mean in that way that it } \\ \text { siinä mielessä et se tulee } & \text { comes naturally that you can } \\ \text { sieltä niinku luonnostaan et } & \text { switch languages just like } \\ \text { pystyy niinku vaihteleen } & \text { that. That it just comes from } \\ \text { kieltä tosta noin että et se } & \text { birth. That it’s not that } \\ \text { on niinku synnyn- } & \text { you've learned a language } \\ \text { synnynnäistä. Et ei silleen } & \text { when you're twenty and then } \\ \text { että on kakskymppisenä } & \text { claim that I'm trilingual. } \\ \text { oppinu jonkun kielen ja sit } & \\ \text { totee et mä on } & \\ \text { kolmikielinen. } & \\ \text { Niin joo ei. } & \end{array}$


Whereas Leena's reference to a mother tongue in the singular is a common discourse in the Finnish context due to the bureaucratic system of registering one official mother tongue, Heikki recycled another discourse, where the mother tongue has emotional connotations and is not necessarily restricted to just one. In defining what it takes to count as bilingual, Heikki presented a complex aggregate of different discourses (Scollon \& Scollon, p. 14): he saw bilingualism as rooted in one's early years, he thought that bilingual means that you can switch effortlessly between the languages, and he thought that the languages are not 'learned' or 'foreign'. Heikki's ideas were grounded in his own historical body and lived experiences, and he ascribed to Tindra a similar identity to his own. Both parents also joyfully reported Tindra's interest in languages such as German and English: Tindra kysyy hirveen usein, että 'mitä kieltä toi on’ [...] et hän tietää että se on saksaa ja on englantia ja niin niin se on niin hauska tosissaan. ("Tindra very often asks, 'what language is that' [...] so she knows that it's

German and that there's English and so on, so that's really nice.”). Still, she was defined as bilingual (rather than multilingual). The reasoning here reminds us of what we found in the Pitkänen family: one can add languages to one's repertoire as one gets older (cf. Excerpt [5] above), but one is bilingual first and foremost by virtue of being born into it or, alternatively, of having attended school in another language than the one spoken at home.

\section{Discussion}

In this paper, we have analysed linguistic identities as (co-)constructed in parental discourses in three multilingual families. In response to the first research question how parents linguistically (and culturally) identified themselves, and negotiated and ascribed identities to each other and to their children - we found that all the families and their members were constructed as multilinguals. Although the term 'multilingual' itself 
was not explicitly employed by any of the parents, it was evident that different languages (Finnish, Swedish, English, German) played significant roles in their own as well as in their children's everyday lives. However, to identify oneself or one's partner as bilingual or multilingual was not straightforward and required negotiation between the parents.

Rather contradictorily, whilst being multilinguals with rich repertoires of inherited as well as acquired language skills, most parents were firm about identifying themselves as a speaker of only one language: olen ihan/aika täysin suominkielinen ("I am definitely/pretty much $100 \%$ a Finnish speaker”) or fullständigt svenskspråkig (100 $\%$ Swedish speaker). This means that identity was primarily defined in terms of belonging to a single (imagined homogenous) group of speakers of a certain language (cf. the concept of 'speaker-hood' in Moore et al., 2010). Moreover, whereas traditions and habits were put forward by one of the couples (Lindström-Kuusisto) to distinguish Finnish speakers from Swedish speakers, ethnicity was not an issue. This stands in contrast to other studies of binational couples, where ethnicity plays a potentially significant role in negotiations of linguistic identity (e.g., Okita, 2002; Piller, 2002).

As for the second research question - how the constructed linguistic identities were related to the parents' own lived experiences and to societally situated discourses and ideologies - we found certain concepts that frequently circulated, such as 'mother tongue(s)', 'bilingual(ism)', and 'foreign' and 'learned language(s)'. These are socially and historically situated concepts known from Finnish national language policy and education policy discourses, as well as colloquial discourse. In the interviews, 'mother tongue' was referred to by some of the parents in terms of the official mother tongue, and hence conceptualised in the singular. Others challenged this concept, attached emotional content to 'mother tongue' and distinguished it from 'foreign language', and 
provided alternative definitions, including the possibility of naming more than one mother tongue as part of one's individual identity.

The parents seemed to conceptualise 'bilingual' as an identity that comes at birth: a child born into a mixed language family had the right to claim and be granted bilingual identity, regardless of their language proficiency or bilingual practices. Moreover, parents were surprisingly firm that a bilingual or multilingual identity could not be achieved or claimed over time, no matter how much they had studied languages formally, or what multilingual practices there might have been in their family or working life as an adult. Identity in this sense, rather than being dynamic and subject to change over time, becomes a matter of essence: it is something you have (i.e. are born into) rather than something you do (i.e. using or acquiring new languages). There were, however, two exceptions to this ideology of nativeness: Tuija and Heikki were both born into families where Finnish was spoken but they attended Swedish-medium schools. In Bourdieu and Passeron's (1977, p. 42-43) terms, while the primary habitus acquired at home in their early years was monolingual, the secondary habitus acquired at school served to give them a bilingual identity as adults. The importance of going to a Swedish school in Finland for the development of a minority language identity on the national as well as the individual level has also been acknowledged elsewhere (e.g. Lojander-Visapää, 2008).

Despite the fact that all the subjects were in practice multilingual, the main discourses circulating in the parental talk can thus be summarised as ascribing to themselves (and others) a monolingual identity unless they had been born into a mixedlanguage family (or attended a minority language school), in which cases they could be ascribed a bilingual identity. Moreover, the societal discourse equating 'bilingualism' with Finnish-Swedish bilingualism in Finland (Halonen et al., 2015; Hult \& Pietikäinen, 
2014) was strongly present in all the arguments. This discourse was most likely grounded in the fact that each citizen is identified with one official mother tongue, in combination with a general conception that there are two distinct language groups in Finland. This concept can be traced all the way back to the Constitution of Finland (1919/1999), where it is stated that "the public authorities shall provide for the cultural and societal needs of the Finnish-speaking and Swedish-speaking populations of the country on an equal basis" (§17) (cf. Ihalainen \& Saarinen, 2015). On the whole, although it was obvious that the participants knew several languages, multilingualism was given only a background role in the discussions.

\section{Conclusion}

The parental talk around the couples' language backgrounds and what it takes to count as bi- or multilingual revealed hybrid identities and multiple discourses (cf. Gonçalves, 2013; Piller, 2002). Across the couples, we could identify a number of co-occurring discourses based on such aspects as proficiency, order of acquisition, affection, nativeness, inheritance and cultural appropriation. Although revealing a tendency to label and categorise identities and pin them onto themselves as well as onto others, essentially seeing identity as something set from birth - hence pursuing a nativeness ideology - the couples also actively negotiated identities and in some cases modified their conceptions while interacting. We further found that all the families applied multilingual language practices within and outside their bilingual homes. However, we also found an equally clear tendency to describe languages learned later as additional, separate pieces glued onto the original identity, rather than being an integral part of it. Ideologies held by individuals or a community mediate - and are mediated through - language use (cf. De Houwer, 1999; Piller, 2002). This study highlights the 
need to further explore the intricate connections between identities, ideologies and agency (Kalaja et al, 2016, p. 18; King \& Lanza, 2017). The study illustrates how systems of social organisation and societal language planning discourses of supporting or safeguarding linguistic rights at a bilingual/multilingual national level can at the same time force monolingual identities onto multilingual individuals. Along with individual lived experiences, societal ideologies and discourses affect how parents define the linguistic identity of their family and its members. We need further research to find out what implications this has for how linguistic identity is passed on across generations. A relevant question to ask in the future is how young children - like Eva, Ella and Tindra, who were all given a bilingual identity by their parents - will identify themselves as adults and how that, in turn, will affect their own language practices, ideologies and life trajectories.

Acknowledgement: This work was supported by the Academy of Finland under Grant No. 266850.

Discloser statement: No conflict of interest was reported by the authors.

\section{References}

Bergroth, M. (2015). Kaksisuuntaista kieleen sosiaalistumista kaksikielisissä perheissä. [Two-way language socialization in bilingual families]. In T. Jakonen, J. Jalkanen, T. Paakkinen \& M. Suni (Eds.), Flows of language learning. AFinLA's Yearbook 2015 (pp. 126-141). Jyväskylä: The Finnish Association for Applied Linguistics.

Block, D. (2007). The rise of identity in SLA research post Firth and Wagner (1997). The Modern Language Journal, 91, 863-876.

Bourdieu, P. \& Passeron, J. C. (1977). Reproduction in education, society, and culture. London: Sage.

Bucholtz, M. \& Hall, K. (2005). Identity and interaction: A sociocultural linguistic approach. Discourse Studies 7(4/5), 585-614. 
Constitution of Finland 1919/1999. Retrieved from http://www.finlex.fi/sv/laki/kaannokset/1999/en19990731.pdf

Curdt-Christiansen, X.-L. (2013). Family language policy: realities and continuities. Language Policy, 12(1), 1-6.

De Houwer, A. (1999). Environmental factors in early bilingual development: the role of parental beliefs and attitudes. In G. Extra \& L. Verhoeven (Eds.), Bilingualism and Migration (pp. 75-95). Berlin: Mouton de Gruyter.

FNBE (Finnish National Board of Education) (2014). National Core Curriculum for Basic Education 2014. Helsinki: Finnish National Board of Education.

Fogle, L.W. (2012). Second language socialization and learner agency: Adoptive family talk. Clevedon: Multilingual Matters.

Gonçalves, K. (2013). 'Cooking lunch, that's Swiss': Constructing hybrid identities based on socio-cultural practices. Multilingua, 32(4), 527-547.

Halonen, M., Ihalainen, P. \& Saarinen, T. (Eds.) (2015). Language Policies in Finland and Sweden. Interdisciplinary and Multi-sited Comparisons. Bristol: Multilingual Matters.

Honko, M. \& Latomaa, S. (2016). Undervisning i och forskning om finska som andraspråk med fokus på nyanlända barn och ungdomar. [Teaching in and research about Finnish as a second language with a focus on newly arrived children and youngsters]. Nordisk tidsskrift om andrespråksforskning, 2016(2), $65-91$.

Hult, F.M. (2015). Making policy connections across scales using nexus analysis. In F. Hult \& D.C. Johanson (Eds.), Research Methods in Language Policy and Planning: A Practical Guide (pp. 215-231). West Sussex: Wiley.

Hult, F.M., \& Pietikäinen, S. (2014). Shaping discourses of multilingualism through a language ideological debate: The case of Swedish in Finland. Journal of Language and Politics, 13(1), 1-20.

Ihalainen, P. \& Saarinen, T. (2015). Constructing 'Language' in language policy discourse: Finnish and Swedish legislative Processes in the 2000s. In M. Halonen, P. Ihalainen \& T. Saarinen (Eds.), Language Policies in Finland and Sweden. Interdisciplinary and Multi-sited Comparisons (pp. 29-56). Bristol: Multilingual Matters.

Kalaja, P., Barcelos, A., Aro, M. \& Ruohotie-Lyhty, M. (2016). Key issues relevant to the studies to be reported: Beliefs, agency and identity. In P. Kalaja, A. 
Barcelos, M. Aro, \& M. Ruohotie-Lyhty (Eds.), Beliefs, Agency and Identity in Foreign Language Learning and Teaching (pp. 8-24). Basingstoke: Palgrave Macmillan.

King, K. \& Fogle, L.W. (2017). Family language policy. In T.L. McCarthy \& S. May (Eds.), Language Policy and Political Issues in Education, Encyclopedia of Language and Education (pp. 315-327). Dordrecht: Springer.

King, K., Fogle, L. \& Logan-Terry, A. (2008). Family language policy. Language and Linguistics Compass, 2(5), 907-922.

King, K. \& Lanza, E. (2017). Ideology, agency, and imagination in multilingual families: An introduction [Special issue]. International Journal of Bilingualism. Advance online publication. DOI: 10.1177/1367006916684907.

Kramsch, C. (2009). The Multilingual Subject. Oxford, NY: Oxford University Press.

Liebkind, K., Tandefelt, M. \& Moring, T. (2007). Introduction: why a special issue on the Swedish-speaking Finns? International Journal of the Sociology of Language 187/188, 1-11.

Lojander-Visapää, C. (2008). New bilingualism in the bilingual Finnish context. Europäisches Journal für Minderheitenfragen, 2, 109-118.

Mann, S. (2016). The research interview. Reflective practice and reflexivity in research processes. Basingstoke: Palgrave Macmillan.

McRae, K.D. (2007). Toward language equality: four democracies compared. International Journal of the Sociology of Language 187/188, 13-34.

Moore, R., Pietikäinen, S., \& Blommaert, J. (2010). Counting the losses: numbers as the language of language endangerment. Sociolinguistic Studies, 4(1), 1-26.

Määttä, S. \& Pietikäinen, S. (2014). Ideology. In J.-O. Östman \& J. Verschueren (Eds.), Handbook of Pragmatics: 2014 Installment (pp. 01-24). Amsterdam: John Benjamins. DOI: 10.1075/hop.18.ide1

Norton, B. (1997). Language, Identity, and the Ownership of English. TESOL Quarterly, 31, 409-429.

Official Statistics of Finland (OSF) 2017. Population structure [e-publication]. Retrieved from http://www.stat.fi/til//vaerak/tau_en.html

Okita, T. (2002). Invisible work. Bilingualism, language choice and childrearing in intermarried families. Amsterdam: John Benjamin. 
O'Rourke, B., Pujolar, J \& Ramallo, F. (2015). New speakers of minority languages: the challenging opportunity - Foreword [Special issue]. International Journal of the Sociology of Languages, 231, 1-20

Palviainen, Å. \& Boyd, S. (2013). Unity in Discourse, Diversity in Practice. The OnePerson One-Language Policy in Bilingual Families. In M. Schwartz \& A. Verschik (Eds.), Successful Family Language Policy: Parents, Children and Educators in interaction (pp. 223-248). Dordrecht, Netherlands: Springer.

Piller, I. (2001). Private language planning: The best of both worlds? Estudios de Sociolingüística, 2(1), 61-80.

Piller, I. (2002). Bilingual couples talk. The discursive construction of hybridity. Amsterdam: John Benjamin.

Schwartz, M. \& Vershik, A. (Eds.) (2013). Successful family language policy. Dordrecht: Springer.

Scollon, R. \& Scollon, S.W. (2004). Nexus analysis. Discourse and the emerging Internet. London: Routledge.

Teiss K. \& Perendi S. (2017). Parental Attitudes and Family Conversational Strategies Shaping the Family Language Policies of two Estonian-Finnish Families (pp. 99-122). In M. Siiner, K. Koreinik, K. Brown (Eds.), Language Policy Beyond the State. Dordrecht: Springer.

Zu Hua \& Li Wei (2016). Transnational experience, aspiration and family language policy. Journal of Multilingual and Multicultural Development, 37(7), 655-666.

\footnotetext{
i Transcription key:

[...] some content left out

[ ] content added for clarity

(( )) non-verbal content

underline stressed content

word- interrupted speech

$=$ word $=$ latched utterances
} 